\title{
Education of Hygiene Sanitation Processing Cane Water Traders as a Prevention of Food Borne Diseases Prevention
}

\author{
${ }^{1}$ Siti Maisyaroh Fitri Siregar, ${ }^{2}$ Khairunnas \\ ${ }^{1}$ Faculty of Public Health, Universitas Teuku Umar, Indonesia \\ ${ }^{2}$ Department of Nutrition, Faculty of Public Health, Universitas Teuku Umar, Indonesia \\ Coresponding author:Siti Maisyaroh Fitri Siregar, e-mail: sitimaisyaroh@utu.ac.id \\ Co-author: K: khairunnas@utu.ac.id \\ Submitted:06/03/2021 Revised:05/04/2021 Accepted:05/04/2021 Published online:13/04/2021 \\ doi: https://doi.org/10.35308/j-kesmas.v7i2.1646. How to cite this article: Siregar, M.F.S \& Khairunnas (2021). Education of \\ Hygiene Sanitation Processing Cane Water Traders as a Prevention of Food Borne Diseases Prevention. J-Kesmas: Jurnal \\ Fakultas Kesehatan Masyarakat (The Indonesian Journal of Public Health). 8(1): 16-20
}

\begin{abstract}
The drink of freshly ground sugarcane from sugarcane stalks has a distinctive aroma. It is cloudy in color and is sold without special packaging, and is sold on the road where the sanitation is poor bacteriological quality is doubtful. Escherichia coli is a bacteria that can contaminate sugarcane juice. The most common drink in West Aceh is sugarcane water. This drink is straightforward to find on the side of the road and is liked by every community. The purpose of this study was to see the effect of education on hygiene and sanitation of sugarcane water treatment and examination of Escherichia coli (E. coli) bacteria in sugarcane water. The research method used quasi-experimental and observational methods. The population in this study were sugar cane traders with a total sample of 20 people. The results showed that there was an effect of education on the sanitation hygiene of sugarcane water treatment and levels of Escherichia Coli in sugarcane water
\end{abstract}

Keywords: Education; Hiegene; Sanitasion; Cane Water; Escherichia Coli

\section{Introduction}

WHO (World Health Organization) states more than 200 diseases that can potentially be transmitted through food. Diseases that are transmitted through food or also known as foodborne diseases (Food Borne Diseases) are infectious or poisoning diseases caused by microbes or agents that enter the body through food consumed (WHO, 2018). A drink of freshly ground sugarcane from sugarcane stalks, has a distinctive aroma of sugarcane, has a yellowish cloudy color and has a chemical composition derived from sugarcane stalks which contain sugar water content up to $20 \%$ and if not immediately drunk in a relatively short time, it will not last long. . the color looks darker brown and the taste quickly changes to acidity (Kusumawati, 2016).

The results of preliminary observations and interviews that have been conducted on sugarcane water traders in West Aceh district consisting of Meureubo sub-district, Kaway XVI sub-district, Johan Pahlawan sub-district. Samples were taken from each sub-district of sugarcane drink traders, including 1 sample Johan Pahlawan District, 1 sample from Meureubo District, 1 sample from Kaway XVI District. As many as 2 traders said that the Escherichia coli bacteria were mostly caused by environmental hygiene factors which were still very poor on how to maintain good and correct hygine sanitation The results of observations in the field of some sugarcane traders do not use direct contact protection with sugarcane stalks which will be processed into sugarcane juice such as not using gloves, masks and the like in processing sugarcane juice. Other sugarcane water traders also said that they still lacked information about how to process and present good sugarcane juice and that many of the equipment and equipment used were not guaranteed clean, seen from some of the equipment used by dirty and rusted sugarcane traders such as grinding machines cane.

The purpose of this study was to determine the effect of education on hygiene and sanitation of sugarcane water treatment at sugarcane water sellers in West Aceh Regency and to determine whether or not the Escherichia coli bacteria were present in sugarcane water drinks in West Aceh Regency.

\section{Methods}

This study used a Quasi-Experimental design, the planned design was one group before and after intervention design, or one group pre and post-test 
design. The population of this study were all sellers of sugarcane juice in West Aceh Regency. Determination of the research sample was carried out using consecutive sampling technique with a total sample of 20 sugarcane drinking water traders in West Aceh Regency. Data obtained from interviews and observations using questionnaires and view sheets, and laboratory examinations, data were analyzed by univariate and bivariate analyzes.

The step of method in implematation of this research are 1). Survey introduction to sugarcane water traders, 2) Licensing to research locations 3). initial data collection (pre-test). 4). observations at the sugarcane water selling kiosk using a check list sheet according to the standards (before education was implemented). 5). Examination of Escehrichia coli bacteria in sugarcane juice to be carried out in the laboratory. 6). Education on hygiene and sanitation for sugarcane water treatment at sugarcane water sellers. 6). Post-test 7). Observation at the kiosk selling sugarcane juice using a check list sheet according to the standard (After education is carried out). 8). Examination of Escehrichia coli. 9). Data processing. 10) data analysis. 11) writing research reports. 12). Dissemination of research results.

\section{Results}

Table 1. Table 1 Distribution of Characteristics of Sellers of Sugarcane Water

\begin{tabular}{lll}
\hline Characteristics & \multicolumn{1}{c}{ F } & \% \\
\hline Sex & & 0 \\
Man & 0 & 100 \\
Women & 20 & \\
Age (Year) & & 10 \\
$20-25$ & 2 & 20 \\
$26-30$ & 4 & 20 \\
$31-35$ & 4 & 50 \\
$>35$ & 10 & \\
Long Trading (year) & & 30 \\
1 & 6 & 5 \\
2 & 1 & 15 \\
3 & 3 & 50 \\
$>4$ & 10 & \\
Last education & & 15 \\
Elementary School & 3 & 15 \\
Junior Hight School & 3 & 65 \\
Senior Hight School & 13 & 5 \\
Bachelor's/Diploma & 1 & \\
\hline Source: Primer Dat, 2020 &
\end{tabular}

Source : Primer Data, 2020

All respondents were female $(100 \%)$, the majority were $>35$ years old $(50 \%)$, the most long trading was $>4$ years $(50 \%)$, the most high school education level $(65 \%)$.
Table 2. Frequency Distribution of Hygiene and Sanitation Scores on Sugarcane Drinks Before Intervention

\begin{tabular}{lcc}
\hline $\begin{array}{l}\text { Hygiene and Sanitation Scores } \\
\text { on Sugarcane Drinks }\end{array}$ & F & $\%$ \\
\hline Sugarcane Selection & 14 & 70 \\
1 & 6 & 30 \\
2 & & \\
Storage of Raw Materials & 13 & 65 \\
(Sugarcane) & 7 & 35 \\
1 & & \\
2 & & \\
Sugarcane Processing (Cane) & 8 & 40 \\
4 & 7 & 35 \\
5 & 2 & 10 \\
6 & 2 & 10 \\
9 & 1 & 5 \\
10 & & \\
Sugarcane Transport & 13 & 65 \\
0 & 1 & 5 \\
1 & 6 & 30 \\
2 & & \\
Serving Sugar Cane Water & 17 & 85 \\
1 & 1 & 5 \\
2 & 2 & 10 \\
3 & & \\
Sugarcane Water Storage & 1 & 5 \\
1 & 15 & 75 \\
2 & 4 & 20 \\
3 & & \\
\hline
\end{tabular}

Source: Primer Data, 2020

The results of the table analysis in table 2 , it is known that the hygiene score and sanitation of drinking water treatment for sugarcane before intervention, the score for selecting sugarcane is at most $1(70 \%)$, the score for storing raw materials (sugarcane) is at most $1(65 \%)$, the score for sugarcane processing is lots of $8(40 \%)$, score of removal of sugarcane at most $0(65 \%)$, score of serving sugarcane juice at most $1(85 \%)$ and score of storage of raw materials (sugarcane) at most $1(75 \%)$. these results ensure that the index of the characteristics of the respondents in a table. the explanation will be explained in more detail below

Tabel 3. Frequency Distribution of Hygiene and Sanitation. 


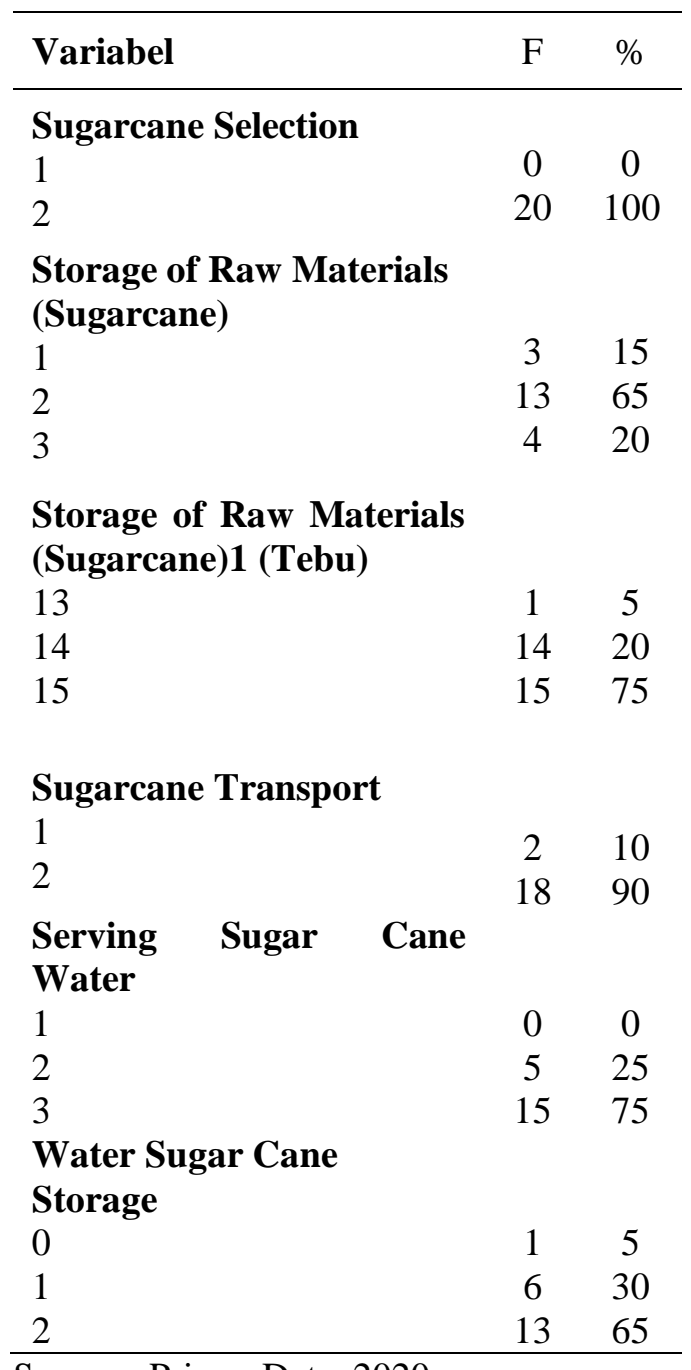

Source : Primer Data, 2020

From table 3 it is known, the score of hygiene and sanitation for drinking water treatment of sugarcane, the score for selecting sugarcane is at most $2(100 \%)$, the score for storing raw materials (sugarcane) is at most $2(65 \%)$, the score for sugarcane processing is at most 15 (75\%), the maximum score for removal of sugarcane is $2(90 \%)$, the score for serving sugarcane juice is at most $3(75 \%)$ and the score for storage of sugarcane juice is at most $2(65 \%)$.

Table 4. Distribution of Frequency of Hygiene and Sanitation

\begin{tabular}{lllll}
\hline \multirow{2}{*}{ Variable } & \multicolumn{3}{c}{ Before } & \multicolumn{3}{c}{ After } \\
& $\mathbf{N}$ & $\boldsymbol{\%}$ & $\mathbf{N}$ & $\boldsymbol{\%}$ \\
\hline Eligable & 0 & 0 & 16 & 80 \\
Not eligable & 20 & 100 & 4 & 20 \\
\hline
\end{tabular}

The results of the analysis in table 4 show that the hygiene and sanitation of sugarcane drinking water treatment before the intervention, namely all respondents of sugarcane drinking water treatment did not meet the requirements of $20(100 \%)$, the results of hygiene and sanitation of sugarcane drinking water treatment after the intervention met the requirements of $16(80 \%)$. (Regulation of the Minister of Health Number 492/Menkes/Per/IV/2010 concerning Require ments for the Quality of Drinking Water).

Table 5. Distribution of Escherichia Coli (E.coli) Bacteria in Sugarcane Drinks Before and After Intervention

\begin{tabular}{lllll}
\hline E. coli content & \multicolumn{2}{l}{$\begin{array}{l}\text { Before } \\
\text { Intervention }\end{array}$} & \multicolumn{2}{l}{$\begin{array}{l}\text { After } \\
\text { Intervension }\end{array}$} \\
\hline & $\mathbf{N}$ & $\mathbf{\%}$ & $\mathbf{N}$ & $\mathbf{\%}$ \\
\hline There no & 3 & 15 & 20 & 100 \\
There are & 17 & 85 & 0 & 0 \\
\hline Sour $:$ Pring
\end{tabular}

Source : Primer Data, 2020

From table 6, it is known that the processing of drinking sugarcane water based on the Escehrichia coli bacteria content before the intervention was carried out at most of the sugarcane water samples did not meet the requirements, namely 17 samples $(85 \%)$, after the intervention all sugarcane water samples met the requirements, namely 20 samples of sugarcane water (100\%). ). (Minister of Health Regulation Number 492 / Menkes / Per / IV / 2010 concerning Requirements for Drinking Water Quality.

Table 7. Distribution of Frequency of Sugarcane Water Drink Processing before and after Intervention (Wixolcon Test)

\begin{tabular}{lccl}
\hline $\begin{array}{l}\text { Sugarcane Drink } \\
\text { Water Processing }\end{array}$ & N & Mean Rank & P Value \\
\hline $\begin{array}{l}\text { Before Intervension } \\
\text { After Intervension }\end{array}$ & 20 & 10.5 & 0.000 \\
\hline Source Primer Data, 2020 & & \\
\hline
\end{tabular}

Source : Primer Data, 2020

From the research results, it is known that the positive ranks or the difference (positive) between the results of hygienic and sanitation. Drinking water treatment at sugarcane traders for before and after the intervention. Here there are 20 positive data $(\mathrm{N})$, which means that 20 sugarcane water traders have improved hygiene and sanitation for sugarcane water treatment from the value before the intervention to the value after the intervention. The average increase is 10.5. The $\mathrm{P}$ value on the statistical test above is worth 0.000 $(<0.005)$, meaning that there are differences in hygiene and sanitation scores before and after the intervention.

Table 5 Results of Regional Health Laboratory Tests for West Aceh Regency on the Content of Escherichia Coli. Bacteria in Sugarcane Drinks Before and After Intervention 


\begin{tabular}{lll}
\hline $\begin{array}{l}\text { Sample } \\
\text { Code }\end{array}$ & $\begin{array}{l}\text { Before } \\
\text { Intervention }\end{array}$ & $\begin{array}{l}\text { After } \\
\text { Intervention }\end{array}$ \\
\hline S1 & 12 & 0 \\
S2 & 4 & 0 \\
S3 & 4 & 0 \\
S4 & 5 & 0 \\
S5 & 4 & 0 \\
S6 & 4 & 7 \\
S7 & 27 & 0 \\
S8 & 9 & 0 \\
S9 & 265 & 0 \\
S10 & 0 & 0 \\
S11 & 67 & 17 \\
S12 & 12 & 2 \\
S13 & 2 & 0 \\
S14 & 0 & 0 \\
S15 & 67 & 0 \\
S16 & 0 & 0 \\
S17 & 16 & 0 \\
S18 & 2 & 0 \\
S19 & $\geq 979$ & 5 \\
S20 & 12 & 0 \\
\hline
\end{tabular}

From Of the 20 sugarcane water samples examined at the Regional Laboratory of West Aceh Regency, of the 20 samples examined, 3 samples tested did not contain Escherichia Coli (E.coli) bacteria, while 17 more samples contained $\mathrm{E}$. The highest coly is found in the sample code (S19), which is $\geq 979 / 100 \mathrm{ml}$. (Before the intervention), while the results of the sample test after being given the intervention of hygiene education and sugarcane water treatment sanitation, it was found that 16 samples tested no longer contained e-coly bacteria.

\section{Discussion}

Hygiene and sanitation of sugarcane drinking water treatment before the intervention, namely all respondents of sugarcane drinking water processing did not meet the 20 requirements $(100 \%)$, this was due to several factors, such as not washing the sugarcane before peeling it, the storage place for raw materials was not clean and impermeable. Some sugarcane traders put raw sugarcane raw materials directly on the floor where they were traded without a base, the handlers did not wear gloves, did not wash their hands every time processing sugarcane juice, did not wear aprons, some traders wore gold jewelry and chatted while processing sugarcane raw materials. There is no running hand washing area available, some utensils are not washed before use, the utensils are not washed under running water and there are no covered bins. The results of this study are in line with research conducted by Sudariyono, R \& Mulyasari, T, M (2018) regarding the hygiene and sanitation of catering services in the buffer area of the Class II Port Health Office of Tanjung Intan Cilacap, it is known that of the 5 food service businesses studied that meet health requirements there are 3 (three) catering service businesses. The results of research by Priyani, A \& Budiono, Z (2017) show that the hygiene and sanitation of food and beverage processing at Banyumas General Hospital does not meet the requirements. Research by Ristoyo, R. et al (2016) of 16 respondents out of 30 respondents who have hygiene and sanitation behavior in processing does not meet the requirements. In line with Ramanda's research, F et al (2017) at the Buffer Food Processing Plant (TPM) in the Adi Sumarmo airport area of Surakarta.

The results of the study concluded that there was an effect of the use of educational methods on the hygiene and sanitation scores of drinking sugarcane water treatment in sugarcane drinking water traders. This research is in line with research conducted by Ningsih, $\mathrm{R}$ (2014) in Samarinda City, there are differences in knowledge, hygiene practices of food and beverage sanitation before and after counseling..The results of counseling by Faisal, A (2015) at the canteen managed by the University of Tanjung Pura Pontianak, health education and food and beverage sanitation effectively increase the knowledge, attitudes and behavior of food handlers. Research by Apriany, D, et all (2019), there is a relationship between sanitation and personal hygiene in ice doger sellers with e.coly content, in line with research conducted by Lado, Y, et all (2020) at WarungLesehan in the Babarsari area, Suryani, D \&Astuti, F, D (2019) at Angkringan Traders in the Malioboro Yogyakarta Area.In line with the research conducted by Rohmah, J. Et all (2019) in the school canteen and in line with the Husna, A \&Fahlevi, M. I (2020) research, education in the form of counseling and training can increase knowledge and skills. This research is also in line with the research of Hutosoit, T.P (2018) at the Class I Port of Medan.

\section{The content of Escherichia Coli (E.coli) bacteria in sugarcane water before and after the intervention}

Sugarcane drinking water treatment based on the Escehrichia coli bacteria content before the intervention, namely the most sugarcane water samples did not meet the requirements, namely 17 samples, after the intervention the most sugarcane water samples met 
the requirements, namely 16 sugarcane water samples. (Regulation of the Minister of Health Number 492 / Menkes / Per / IV / 2010 concerning Requirements for the Quality of Drinking Water).In line with this research is in line with the research of Wardana, A, A, et all (2020) on fruit soup drinks on the campus of Jenderal Soedirman University. Research by Ristoyo, R, et all (2016) at the elementary school in Watu agung village, added, Banyumas district. In line with the research conducted by Azwar, A, et al (2020) on the refill gallon of drinking water in Samatiga sub-district, it is known that from the 7 samples studied, 6 samples positively contained the e.coly bacteria.In line with research conducted by Simnajuntak (2018) sugarcane water traders around the city of Medan, it was found that 30 samples of sugarcane water that were examined contained E.coly bacteria. Research conducted by Ristoyo, R et al (2016) on sauces food, 15 food samples containing escherchia coli. In a study conducted by Nuraya A, D \& Nindya, T, S (2018), escherichia coli bacteria were found in a sample of layered cake snacks.This research is also in line with research conducted by Noviana, N \& Ruhban, A (2020) on burgers sold by street vendors

\section{Acknowledgement}

Thank you researcher offered to KEMENRISTEK DIKTI for the aid of the cost of the PDP scheme in 2020 and thanks to the head of district Meureubo, head of district Johan Pahlawan and head of district KawayXVI who has given research permit.

\section{Author Contribution and Competing Interest}

The author's contribution to this research is to be involved in the design of a research project, collect data, take samples or analysis results, be involved in the preparation or revision of scientific works.

\section{References}

Abdullah, F (2015). EfektivitasPenyuluhan Hygiene dan SanitasiterhadapPeningkatanPengetahuan, Sikap dan PerilakuPenjamahmakanan di Kantin yang dikelola Universitas Tanjung Pura Pontianak. 3(1):6-11

Apriany 1 (2019). HubunganSanitasi dan Personal HigienedenganKandungan E-Coli pada Penjual Es Doger di Kecamatan Medan Amplas. Jurnal Kesehatan Global. 2(2):103.

Azwar. A (2020). Escherchia Coli Content in Refill Drinking Water (AMMU) in Samatiga District, West Aceh Regency. Jkemas 7(2).
Hutasoit, T,P (2018). Tingkat Hygiene Penjamah Makanan di Pelabuhan Kelas I Medan. Jurnal Ilmu Kesehatan Masyarakat. 7(3):141-147

Lado. RY. (2020). AnalisisHigieneSanitasi dan KeberadaanBakteri Escherichia Coli pada PeralatanMakan (Piring) di WarungLesehan pada Wilayah Babarsari. 5 isue 1 (2020):20-28 .

Ningsih, R (2014). Penyuluhan Hygiene dan SanitasiMakanan dan Minuman, sertaKualitasMakanan yang di jajakan di Lingkungan SDN Kota Samarinda. KemasJurnal Kesehatan Masyarakat. 10 (1).

Nuraya, A, D \& Nindi, T,S. Hubungan Praktek Personal Hygene pedagang dengan keberadaan bakteri escherchia coli dalam jajanan kue lapis di Pasar Kembang Kota Surabya. Media Gizi Indonesia. 12(1):7

Priyani, A \& Budiono, Z (2017). Studi Hygiene dan Sanitasi Pengelolaan Makanan dan Minumandi RSUD Banyumas Kabupaten Banyumas. Buletin Kesling Gmas. 37(3):316-322

Ramanda, F. (2017). Hubungan Personal Hygene dan Keberadaan keberadaan escherichia coli pada makanan di Tempat pengolahan Makanan (TPM) Buffer area Bandara adi SoemarmoSurakarta. Biomedika. 8(1)

Ristoyo, R (2016). Hubungan Hygiene dan Sanitasi dengan Kontaminasi escherichia coli pada Jajanan bersaus pada Pendidikan Sekolah Dasar se-wilayah desa Wutaagung Kecamatan Tambak Kabupaten Banyumas. Buletin Keslingmas. 35(4):377-382

Suryani, D \&Astuti, F, D (2019).Higiene dan Sanitasi pada PedagangAngkringan di Kawasan Malioboro Yogyakarta. JurnalKedokteran dan Kesehatan. 15(1):170

Simanjuntak, B, MP (2018). Tingkat Hygiene dan kandungan e coli pada air tebu yang dijualsekitar Kota Medan.Jurnal Kesehatan. 9(2):214-217

Sudariyono, R \& Mulyasari, T, M (2018) tentang hygiene dan sanitasi jasa boga di wilayah buffer Kantor Kesehatan Pelabuhan Kelas II Tanjung Intan Cilacap. Buletin Kesling Gmas. 37(3):24024 